\title{
Comparison of indomethacin and phenylbutazone in acute gout
}

\author{
CHARLEY J. SMYTH* AND JOHN S. PERCY $\dagger$ \\ From the University of Colorado School of Medicine, Denver, Colorado, and the Department of Medicine, \\ University of Alberta, Edmonton, Alberta, Canada
}

At the present time, a number of drugs are known to be effective in the treatment of acute gouty arthritis. Colchicine is perhaps the best known of these, and has the virtue of antiquity, but its value is restricted by the occurrence of unpleasant though usually harmless side-effects.

Phenylbutazone has been in use for almost two decades and has a rapid clinical effect similar to that of cholchicine when these drugs are given orally in acute gout (Freyberg, 1962; Wilson, Huffman, and Smyth, 1956). Reservations are often expressed about the use of this drug, on the grounds that it is a known cause of bone marrow depression. The majority of reports of severe reactions show a marked relation to the total dosage administered. The remainder of these reactions appear to be due to individual hypersensitivity, which is apparently unrelated to previous drug exposure, and is not enhanced after a subsequent administration (Dvorak and Blaszkova, 1965; Meiers, Gehrmann, and Gahlen, 1963). Such reactions have not been observed by the authors in a 10-year period, during which more than 200 gouty patients have been treated with this drug. From an extensive review of the literature, reactions from phenylbutazone in gouty patients must be considered to be extremely rare. In view of its therapeutic efficiency, and the rarity of toxic reactions in short-term treatment, phenylbutazone is regarded by some as the drug of choice in acute gout (Barnes, 1967; Boland, 1966).

Indomethacin has been shown by many uncontrolled studies to be highly effective in the treatment of acute gout (Berman, 1965; Emmerson, 1967; Hart and Boardman, 1963; Norcross, 1963; Smyth, Velayos, and Amoros, 1963a). Boardman and Hart (1965) attempted to compare its efficacy with that of phenylbutazone and colchicine in producing symptomatic relief of this condition. On this single subjective parameter, indomethacin was found to be superior to both alternative compounds in 26 patients with 38 acute attacks, although the failure rate of those patients receiving colchicine ( 75 per cent.) is astonishingly high. In this study no objective measurements were reported. Nausea, diarrhoea, and other sideeffects occurred in 50 per cent. of patients receiving colchicine, whilst 30 per cent. of patients receiving indomethacin complained of untoward effects (headaches, giddiness, nausea, etc.). In contrast, phenylbutazone produced only one side effect (melaena) in a single patient.

The current drugs of choice for the treatment of acute gout appear to be indomethacin and phenylbutazone, and the recorded serious toxic effects of the latter drug are not a problem when it is used in the small total amount required for the therapy of acute gout. There is a surprising paucity of publications on the relative merits of indomethacin and phenylbutazone in acute gout in the recent medical literature. This double-blind study of the effects of the two drugs with measurements of all available parameters in 31 attacks of acute gout occurring in 28 patients is therefore timely.

\section{Methods}

Patients suffering from acute gout were seen daily, either as out-patients, or as in-patients in the Colorado General Hospital or the Veterans Administration Hospital in Denver. The diagnosis was established on generally accepted clinical grounds. None of the patients had radiological evidence of intra-articular calcification.

Both drugs were administered in identical gelatin capsules, containing either indomethacin $25 \mathrm{mg}$. or phenylbutazone $100 \mathrm{mg}$. The dosage plan was two capsules every $6 \mathrm{hrs}$ for four doses (total $200 \mathrm{mg}$. indomethacin or $800 \mathrm{mg}$. phenylbutazone in the first $24 \mathrm{hrs}$ ). The dosage frequency was then reduced to every $8 \mathrm{hrs}$ for three doses (total $150 \mathrm{mg}$. indomethacin or $600 \mathrm{mg}$. phenylbutazone in $24 \mathrm{hrs}$ ) and subsequently continued as one capsule every $6 \mathrm{hrs}$ (total $100 \mathrm{mg}$. indomethacin or $400 \mathrm{mg}$. phenylbutazone in $24 \mathrm{hrs}$ ) until one day after all signs of inflammation had subsided. Choice of therapy was determined by blind selection of containers coded according to a restricted series of random numbers. Neither the patient 
nor the investigator was aware which drug was used until after the cessation of treatment.

Daily measurements were made of the volumes of the affected and unaffected extremities in 27 patients, using an accurate water displacement method (Smyth and others, 1963a). Daily clinical estimates were made of the amount of pain, tenderness, redness, heat, swelling, and joint effusion, using an arbitrary 1 to 4 scale. In addition, the patient was asked to note when he considered his pain to have subsided sufficiently for him to resume normal activities. Any side-effects were noted, and frequent measurements of the haematocrit, leucocyte count, and erythrocyte sedimentation rate were made. Daily uric acid estimations were performed, using a uricase method (Praetorius and Poulsen, 1953).

\section{Results}

31 acute attacks of gout, occurring in 28 patients, have been treated; fifteen attacks with indomethacin and sixteen with phenylbutazone. One patient had two attacks treated with indomethacin and two patients each had two attacks treated with phenylbutazone. The composition of the two treatment groups is compared in Table I. There were more patients with first attacks of acute gout treated with indomethacin and conversely there were more patients with a long history of repeated attacks and with tophi in the group treated with phenylbutazone. However, there was no statistically significant difference between any of the parameters in the two groups.

Table I Comparison of treatment groups Mean value with range in parentheses

\begin{tabular}{|c|c|c|}
\hline Drug & Phenylbutazone & Indomethacin \\
\hline $\begin{array}{c}\text { No. of patients Male } \\
\text { Female }\end{array}$ & $\begin{array}{r}13 \\
2\end{array}$ & $\begin{array}{r}14 \\
2\end{array}$ \\
\hline Age (yrs) & $63(45-77)$ & $57(30-73)$ \\
\hline $\begin{array}{l}\text { Duration of attack } \\
\text { before beginning } \\
\text { therapy (days) }\end{array}$ & $4(1-10)$ & $3(1-7)$ \\
\hline No. of patients & & \\
\hline $\begin{array}{l}\text { With first attack } \\
\text { With ten or more } \\
\text { attacks }\end{array}$ & $\begin{array}{l}2 \\
7\end{array}$ & $\begin{array}{l}5 \\
4\end{array}$ \\
\hline With tophi & 6 & 3 \\
\hline $\begin{array}{l}\text { Serum uric acid level at } \\
\text { onset (mg. per cent.) }\end{array}$ & $8 \cdot 2(3 \cdot 9-11 \cdot 2)$ & $9 \cdot 2(6 \cdot 3-13 \cdot 1)$ \\
\hline $\begin{array}{l}\text { White cell count at } \\
\text { onset (per mm. }{ }^{3} \text { ) }\end{array}$ & $\begin{array}{l}9,200 \\
(6,550-12,200)\end{array}$ & $\begin{array}{l}8,900 \\
(4,900-13,500)\end{array}$ \\
\hline $\begin{array}{l}\text { Erythrocyte sedimenta- } \\
\text { tion rate at onset } \\
\text { (mm./1st hr) } \\
\text { (Wintrobe) }\end{array}$ & $43(14-57)$ & $26(3-49)$ \\
\hline
\end{tabular}

The results of therapy on the clinical manifestations of the acute attack are shown in Table II. The signs of acute joint inflammation appeared to subside $\Rightarrow$ more rapidly in patients who received indomethacin than in those who received phenylbutazone. There? were three recurrences of acute gout after indomethacin therapy and only one after phenylbutazone. $\frac{\bar{\infty}}{\overparen{D}}$

Table II Days required for resolution of clinical@ signs (to nearest whole day)

(Mean value with range in parentheses)

\begin{tabular}{|c|c|c|}
\hline Drug & Phenylbutazone & Indomethacin \\
\hline $\begin{array}{l}\text { Complete subjective } \\
\text { relief }\end{array}$ & $5(2-17)$ & $5(2-13)$ \\
\hline $\begin{array}{l}\text { Complete resolution } \\
\text { Rest pain } \\
\text { Tenderness } \\
\text { Resolution Heat } \\
\text { Erythema } \\
\text { Swelling }\end{array}$ & $\begin{array}{l}4(1-11) \\
6(2-17) \\
3(1-8) \\
3(1-8) \\
6(1-17)\end{array}$ & $\begin{array}{l}3(1-6) \\
4(1-7) \\
2(1-4) \\
2(1-4) \\
3(1-6)\end{array}$ \\
\hline $\begin{array}{l}\text { No. of recurrences } \\
\text { within } 14 \text { days }\end{array}$ & 1 & 3 \\
\hline $\begin{array}{l}\text { No. of patients } \\
\text { complaining of } \\
\text { toxicity }\end{array}$ & 1 (pitting oedema) & 1 (drowsiness) \\
\hline
\end{tabular}

The results of therapy, as reflected by the more objective measurements made during the acute attack, are shown in Table III. It is to be noted that both the affected and unaffected members shrank in volume after therapy with indomethacin. Reduction in $\overrightarrow{\overrightarrow{0}}$ volume of the affected member was much less marked 3 in the phenylbutazone-treated groups in which the unaffected extremity actually increased in volume. The? fall in the mean serum uric acid level after phenylbutazone was marked $(-2.9 \mathrm{mg}$. per cent.) whereas $\underline{0}$ no real change was noted after indomethacin. This difference is highly significant $(P<0.001)$. The erythrocyte sedimentation rate was more markedly reduced after phenylbutazone and the difference between the groups is significant $(P<0.05)$.

\section{Discussion and conclusions}

From the results of this double-blind study of comparable groups of patients, it can be seen that little 0 difference has been shown between the therapeutice efficacy of indomethacin and phenylbutazone in acute gout, at the dosages used. In this study, both objectiveo and subjective measurements of the acute gout attack have been applied.

The reduction in volume of both the affected and $\underline{T}$ unaffected extremities after indomethacin is in accord $\stackrel{0}{\circ}$ with previous experience in this clinic (Smyth, $\stackrel{\mathbb{P}}{\mathbb{Q}}$ Velayos, and Hlad, 1963b). It is known that the asymptomatic contralateral member swells in acuteo gout, because of increased blood flow (Wolfson and $\Omega$ Robinson, 1951). This phenomenon, together with 
Table III Comparison of changes in objective measurements (Mean value with range in parentheses)

\begin{tabular}{|c|c|c|}
\hline Drug & Phenylbutazone & Indomethacin \\
\hline $\begin{array}{l}\text { Volume of affected member (cu. } \mathrm{cm} .)^{*} \\
\text { Volume of unaffected member (cu. } \mathrm{cm} .)^{*} \\
\text { Serum uric acid level (mg. per cent.) } \dagger \\
\text { White cell count (per } \mathrm{mm}^{3} \text {.) } \\
\text { Erythrocyte sedimentation rate (Wintrobe) } \\
\text { (mm./1st hr) }\end{array}$ & $\begin{array}{l}-25(+64 \text { to }-97) \\
+42(-10 \text { to }+108) \\
-2 \cdot 9(-0 \cdot 2 \text { to }-5 \cdot 2) \\
-1800(-5,500 \text { to }+1,750) \\
-11(-2 \text { to }-24)\end{array}$ & $\begin{array}{l}-89(0-\text { to }-157) \\
-10(+40 \text { to }-36) \\
+0 \cdot 2(-0 \cdot 7 \text { to }+1 \cdot 3) \\
-1125(-5,150 \text { to }+1,900) \\
-3(+5 \text { to }-11)\end{array}$ \\
\hline
\end{tabular}

$* \mathrm{P}<0.01$.

$+\mathrm{P}<0.001$.

reduction in volume after suppression of inflammation in the affected extremity, is of uncertain mechanism. The less marked reduction in swelling of the affected extremity and increase in size of the unaffected member after phenylbutazone is probably due to the sodium-retaining action of this drug (Brodie, Lowman, Burns, Lee, Chenkin, Goldman, Weiner, and Steele, 1954). This caused pitting oedema in one patient in this series; two other patients in the phenylbutazone-treated group had ischaemic heart disease but encountered no side-effects from the drug.

The marked fall in serum uric acid after this short course of phenylbutazone is possibly beneficial, and may account for the trend towards a lower number of recurrences immediately after the treated attack in the patients who had received this drug. The greater decrease in the erythrocyte sedimentation rate after phenylbutazone may have resulted from the fact that this group of patients had higher initial values.

The almost complete absence of side-effects with indomethacin is of interest and confirms our previous clinical impression that patients suffering from acute gout appear better able than other patients to tolerate large doses of indomethacin (Smyth, 1970).

The authors wish to thank Dr. J. F. Bravo for his help with some of the clinical measurements and Dr. T. Terzakis, formerly of Geigy-Ciba Pharmaceuticals, Ardsley, New York, who provided the coded capsules of indomethacin and phenylbutazone.

\section{References}

Barnes, C. G. (1967) J. roy. Coll. Physcns (Lond.), 1, 427 (The treatment of gout)

BERMAN, L. (1965) S. Afr. med. J., 39, 979 (Current trends in therapy of rheumatoid conditions)

Boardman, P. L., AND Hart, F. Dudley (1965) Practitioner, 194, 560 (Indomethacin in the treatment of acute gout)

Boland, E. W. (1966) Calif. Med., 105, 249 (Gout and gouty arthritis-current concepts and management)

Brodie, B. B., Lowman, E. W., Burns, J. J., Lee, P. R., Chenkin, T., Goldman, A., Weiner, M., And Steele, J. M. (1954) Amer.J. Med., 16, 181 (Observations on the anti-rheumatic and physiologic effects of phenylbutazone (Butazolidin) and some comparisons with cortisone)

DVORAK, K., AND BlaZKoVa, E. (1965) Vnitr. Lek., 11, 1000 (Acute thrombocytopenic purpura after phenylbutazone)

EMmerson, B. T. (1967) Brit. med. J., 2, 272 (Regimen of indomethacin therapy in acute gouty arthritis)

FreYBerg, R. H. (1962) Arthr. and Rheum., 4, 624 (Gout)

HaRT, F. Dudley, AND BoARdman, P. L. (1963) Brit. med. J. 2, 965 (Indomethacin: a new non-steroid antiinflammatory agent)

Meiers, H. G., Gehrmann, G., ANd Gahlen, W. (1963) Dtsch. med. Wschr., 88, 580 (Thrombocytopenic purpura due to antibodies following phenylbutazone treatment)

NorCross, B. M. (1963) Arthr. and Rheum., 6, 290 (Treatment of connective tissue diseases with a new non-steroidal compound (Indomethacin))

Praetorious, E., AND Poulsen, H. (1953) Scand. J. clin. Lab. Invest., 5, 273 (Enzymatic determination of uric acid)

SмYтн, C. J. (1970) Ann. intern. Med., 72, 430 (Indomethacin-its rightful place in treatment)

—, Velayos, E. E., AND Amoroso, C. (1963) Acta rheum. scand., 9, 306 (A method for measuring swelling of hands and feet. Part II. Influence of new anti-inflammatory drug, Indomethacin in acute gout)

- - - AND HLAD, C. J. (1963) Ibid., 9, 293 (A method for measuring swelling of the hands and feet. Part I. Normal variations and applications in inflammatory joint diseases)

Wilson, G. M., Huffman, E. R., AND Smyth, C. J. (1956) Amer. J. Med., 21, 232 (Oral phenylbutazone in the treatment of acute gouty arthritis)

WolfSON, W. Q., AND RoBInson, W. D. (1951) J. Lab. clin. Med., 38, 961 (A vascular disturbance as the local mechanism of the acute attack of gout: its rapid reversal by adequate treatment with ACTH) 